\title{
Phenotypic plasticity of wings in selection lines of Drosophila melanogaster
}

\author{
ESTELLE J. K. NOACH*, GERDIEN DE JONG \& WILLEM SCHARLOO \\ Population Genetics, Department of Botanical Ecology and Evolutionary Biology, University of Utrecht, Padualaan 8 , \\ NL-3584 CH Utrecht, The Netherlands
}

\begin{abstract}
Plasticity in wing characters was investigated in lines selected for long and short wing length and for long and short thorax length in Drosophila melanogaster. Selection lines were reared at $20^{\circ} \mathrm{C}$ and at $25^{\circ} \mathrm{C}$. All lines were raised across a temperature range from $17.5^{\circ} \mathrm{C}$ to $27.5^{\circ} \mathrm{C}$ after several generations of directional selection. We tested whether correlated responses in wing cell size and cell number and in plasticity occurred as a result of selection on wing size or thorax size. A difference in plasticity in the lines was observed at different selection temperatures. Selection at $25^{\circ} \mathrm{C}$ resulted only in a change in mean values, whereas selection at $20^{\circ} \mathrm{C}$ led to some correlated responses in plasticity. Different results might have been obtained if more replicates of the selection lines had been started from the same population. The results show that mean size at a temperature and plasticity across temperatures are at least partly determined by different genes.
\end{abstract}

Keywords: Drosophila, phenotypic plasticity, selection lines, temperature, wing.

\section{Introduction}

Phenotypic plasticity (i.e. the dependence of the phenotype of a genotype on environmental conditions) has recently attracted much attention from evolutionary ecologists. Important aspects of the discussion are the adaptive significance of phenotypic plasticity, its evolution and its genetic determination. An especially heated subject of discussion is the question of whether plasticity is a character by itself, i.e. that specific genes or genotypes determine plasticity, or whether a change in plasticity is always a consequence of the selective change in mean values of the phenotype (Scheiner, 1993; Schlichting, 1993; Via, 1993; de Jong, 1995; Via et al., 1995).

Via \& Lande (1985) and Via (1987) use the 'character state' approach (Falconer, 1952), in which one trait, expressed in two different environments, is regarded as two different traits. In their model, they show that an independent change in trait means in the two environments is not possible when a total genetic correlation exists between the two character states. An independent change in two character states requires a less than total genetic correlation between environments. Plasticity is regarded as the difference between character states in the environments, i.e. as totally secondary. In contrast, Scheiner

\footnotetext{
*Correspondence. E-mail: s.noach@boev.biol.ruu.nl
}

\& Lyman $(1989,1991)$ propose (following Bradshaw, $1965)$ that phenotypic plasticity is a character in itself, which can change independently of the overall trait mean. Both selection on the trait and selection on phenotypic plasticity of that trait can be performed separately, because different genes exist for a trait and for plasticity of that trait. Plasticity and overall trait mean are determined by the genetic system, and character states follow from these.

In the present paper, the plasticity of body size in Drosophila melanogaster has been investigated. Artificial selection on wing length and on thorax length has been performed separately at two different temperatures. We tested whether changes in the mean values of the artificially selected characters caused changes in the phenotypic plasticity of these characters. Furthermore, the changes in wing length have been analysed in terms of cell size and cell number. This may give an insight into the basis of genetic and environmental effects.

\section{Materials and methods}

\section{Stocks and rearing}

Flies were caught from a suburban population in Montpellier (France) in October 1990. Stocks were kept at $17.5^{\circ} \mathrm{C}$ with $24 \mathrm{~h}$ light and a humidity of approximately 60 per cent until the start of the experiments. Several weeks before the various selec- 
tion lines were started, one subset of flies was moved to $20 \pm 0.3^{\circ} \mathrm{C}$ and another subset to $25 \pm 0.3^{\circ} \mathrm{C}$. Flies were reared on $20 \mathrm{~mL}$ of a standard cornmeal medium (13 g of agar, $20 \mathrm{~g}$ of yeast powder, $60 \mathrm{~g}$ of cornmeal, $80 \mathrm{~g}$ of sugar and $1 \mathrm{mg}$ of nipagine in $1000 \mathrm{~cm}^{3}$ of water).

\section{Measurements}

Flies were placed on their backs to measure wing length from the middle of the anterior cross-vein to the end of the third longitudinal vein of the right wing. Flies were put on their left sides to measure thorax length from the proximal point of the thorax to the end of the scutellum. All statistical computations were done with sPSS 5.0 and 5.0.1 for Windows.

A one-to-one relationship exists between the number of cells in the wing and the number of trichomes on the wing surface (Dobzhansky, 1929). Right wings of female flies were microscopically examined (objective $25 \times$, projective $2.0 \times$ ) and scanned with a Panasonic black and white CCD camera, type WC-CD50. With the IBAS image analysis system (Korton/Zeiss, Eching, Germany), the trichomes in a standard area of $0.01419 \mathrm{~mm}^{2}$ were counted in the first posterior cell, equidistant from the fourth longitudinal vein, the posterior cross-vein and the third longitudinal vein. Cell size and cell number in the total wing were calculated as: cell size $=$ measured area/counted cells; cell number $=($ counted cells $/$ measured area $) \times($ wing area $/ 100)$.

\section{Parent-offspring regression and selection lines}

Parent-offspring $(\mathrm{P}-\mathrm{O})$ regressions were performed in duplo to estimate the heritability of wing length and thorax length, at two temperatures, $20^{\circ} \mathrm{C}$ and $25^{\circ} \mathrm{C}$, according to the as rtative mating approach (Reeve, 1961; Falconer, 1s 39, table 10.6). Parental flies were measured (50 pairs of each temperature for the wing length $\mathrm{P}-\mathrm{O}$ regression and 50 pairs of each temperature for the thorax length $\mathrm{P}-\mathrm{O}$ regression), originating from jars containing a maximum of 150 eggs. From each parental pair, three female and three male offspring were measured. Wing length was measured as a correlated character in the $\mathrm{P}-\mathrm{O}$ regression analysis of the thorax length.

Selection lines for long and short thorax length and for long and short wing length were started separately at $20^{\circ} \mathrm{C}$ and $25^{\circ} \mathrm{C}$. Every generation was started with three groups of four pairs of flies. A cyclical mating system was used to minimize inbreeding (Robertson \& Reeve, 1952). Eggs were raised on a Mittler-Bennett medium (Mittler \& Bennett, 1962), with a maximum of 100-150 eggs in each jar.

Selection started after two generations of random breeding. Twenty males and 20 females were measured from each culture. The four pairs of flies with the longest measurements from each culture (total 12 pairs of flies) and the four pairs with the shortest measurements from each culture were used to start the long and short lines, respectively. Three groups of four pairs of a second set of flies were
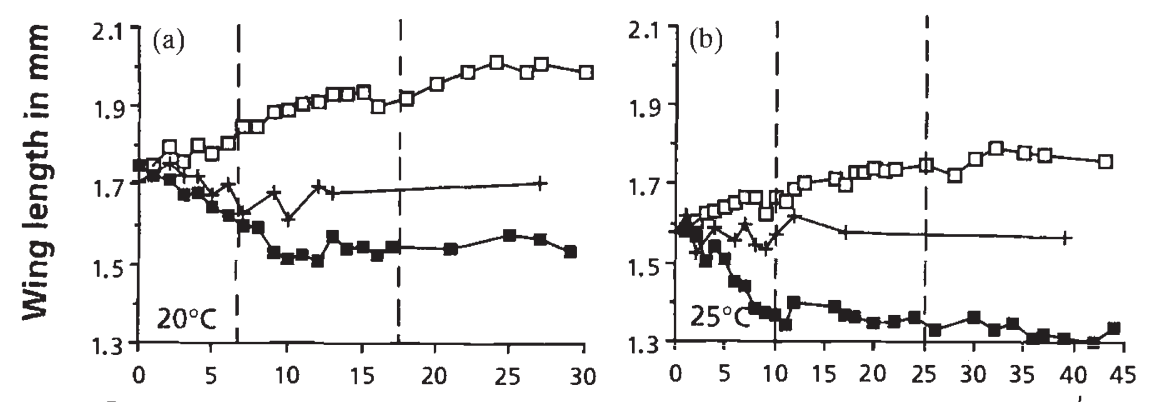

Fig. 1 (a) Wing length plotted against generation of selection for females at $20^{\circ} \mathrm{C}$. (b) Wing length plotted against
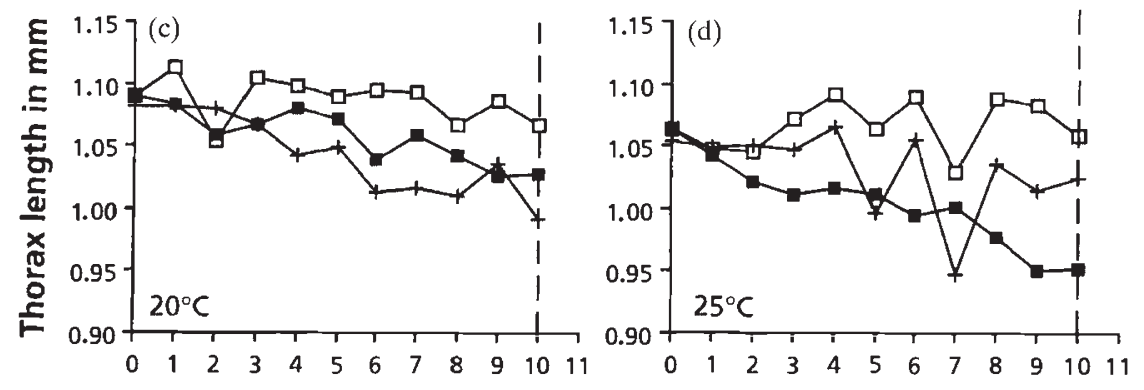
generation of selection for females at $25^{\circ} \mathrm{C}$. (c) Thorax length plotted against generation of selection for females at $20^{\circ} \mathrm{C}$. (d) Thorax length plotted against generation of selection for females at $25^{\circ} \mathrm{C}$. Vertical dotted lines indicate the generations in which temperature exchange experiments have been performed. $\square$, long lines; +, control lines; $\square$, short

Generation lines. 
chosen at random to start the control line. Every generation, 20 flies of each sex and of each line from each culture were measured. Directional selection was carried out over 10 generations. Thereafter, selection in the wing length lines was continued every second generation until generation 29 at $20^{\circ} \mathrm{C}$, and until generation 44 at $25^{\circ} \mathrm{C}$.

\section{Temperature exchange}

Three temperature exchange experiments were performed. In exchange I, jars with eggs (maximum 150 per jar) of the $20^{\circ} \mathrm{C}$ wing length selection lines were reared at $20^{\circ} \mathrm{C}$ and $25^{\circ} \mathrm{C}$ in generation 7 . In exchange II, eggs (40 per vial) of the $20^{\circ} \mathrm{C}$ wing length selection lines were reared at $17.5^{\circ} \mathrm{C}, 20^{\circ} \mathrm{C}$,

Table 1 (a) Heritabilities $\left(h^{2}\right) \pm$ SE and co-heritabilities $\left(\right.$ co- $\left.h^{2}\right) \pm$ SE of the parent-offspring regressions (males and females) of wing length and thorax length at $20^{\circ} \mathrm{C}$ and $25^{\circ} \mathrm{C}$

\begin{tabular}{cccccc}
\hline & \multicolumn{2}{c}{ Wing length } & & \multicolumn{2}{c}{ Thorax length } \\
\cline { 3 - 3 } \cline { 5 - 6 } & $h^{2}$ & co- $h^{2}$ & & $h^{2}$ & co- $h^{2}$ \\
\hline $20^{\circ} \mathrm{C}$ & $0.173 \pm 0.20$ & $0.269 \pm 0.14$ & & $0.428 \pm 0.09$ & $0.258 \pm 0.08$ \\
$25^{\circ} \mathrm{C}$ & $0.490 \pm 0.11$ & $0.238 \pm 0.07$ & & $0.450 \pm 0.20$ & $0.506 \pm 0.15$ \\
\hline
\end{tabular}

(b) Realized heritabilities $( \pm$ SE) in flies selected on wing length

\begin{tabular}{|c|c|c|c|}
\hline & & $\begin{array}{l}\text { Direct response } \\
\text { Wing length } \\
h^{2}\end{array}$ & $\begin{array}{c}\text { Correlated response } \\
\text { Thorax length } \\
\text { co- } h^{2}\end{array}$ \\
\hline $20^{\circ} \mathrm{C}$ Long & $\begin{array}{l}0 \\
0 \\
+\end{array}$ & $\begin{array}{l}0.329 \pm 0.036 \\
0.300 \pm 0.036\end{array}$ & $\begin{array}{l}0.555 \pm 0.322 \\
0.073 \pm 0.044\end{array}$ \\
\hline $20^{\circ} \mathrm{C}$ Short & $\begin{array}{l}0 \\
0 \\
q\end{array}$ & $\begin{array}{l}0.247 \pm 0.021 \\
0.385 \pm 0.017\end{array}$ & $\begin{array}{l}0.019 \pm 0.017 \\
0.081 \pm 0.017\end{array}$ \\
\hline $25^{\circ} \mathrm{C}$ Long & $\begin{array}{l}x \\
0 \\
+\end{array}$ & $\begin{array}{l}0.132 \pm 0.234 \\
0.185 \pm 0.038\end{array}$ & $\begin{array}{l}0.025 \pm 0.024 \\
0.019 \pm 0.036\end{array}$ \\
\hline $25^{\circ} \mathrm{C}$ Short & $\begin{array}{l}\hat{0} \\
0 \\
+\end{array}$ & $\begin{array}{l}0.686 \pm 0.060 \\
0.501 \pm 0.037\end{array}$ & $\begin{array}{l}0.185 \pm 0.037 \\
0.123 \pm 0.028\end{array}$ \\
\hline
\end{tabular}

(c) Realized heritabilities ( \pm SE) in flies selected on thorax lengths

\begin{tabular}{|c|c|c|c|}
\hline & & $\begin{array}{c}\text { Direct response } \\
\text { Thorax length } \\
h^{2}\end{array}$ & $\begin{array}{l}\text { Correlated response } \\
\text { Wing length } \\
\text { co- } h^{2}\end{array}$ \\
\hline $20^{\circ} \mathrm{C}$ Long & $\begin{array}{l}\hat{0} \\
\uparrow\end{array}$ & $\begin{array}{r}0.043 \pm 0.067 \\
-0.055 \pm 0.042\end{array}$ & $\begin{array}{l}-0.039 \pm 0.082 \\
-0.021 \pm 0.054\end{array}$ \\
\hline $20^{\circ} \mathrm{C}$ Short & $\begin{array}{l}\hat{0} \\
q\end{array}$ & $\begin{array}{l}0.147 \pm 0.040 \\
0.109 \pm 0.052\end{array}$ & $\begin{array}{l}0.235 \pm 0.052 \\
0.277 \pm 0.056\end{array}$ \\
\hline $25^{\circ} \mathrm{C}$ Long & $\begin{array}{l}\hat{0} \\
q\end{array}$ & $\begin{array}{l}0.048 \pm 0.075 \\
0.068 \pm 0.061\end{array}$ & $\begin{array}{l}-0.021 \pm 0.074 \\
-0.074 \pm 0.070\end{array}$ \\
\hline $25^{\circ} \mathrm{C}$ Short & $\begin{array}{l}\hat{8} \\
0\end{array}$ & $\begin{array}{l}0.252 \pm 0.044 \\
0.292 \pm 0.029\end{array}$ & $\begin{array}{l}0.375 \pm 0.230 \\
0.248 \pm 0.054\end{array}$ \\
\hline
\end{tabular}

Realized heritabilities were calculated in the first 10 generations from the cumulative selection responses and the cumulative selection differentials (Falconer, 1989). Realized co-heritabilities in thorax length (b) and wing length (c). 
Table 2 Two-factor ANOva with factors line and developmental temperature on characteristics measured on female flies in exchange experiment II

\begin{tabular}{cccc}
\hline & Wing length & Ln (cell number) & Ln (cell size) \\
\hline (a) & & & \\
Dev temp & $* * *$ & $* * *$ & $* * *$ \\
Line & $* * *$ & $* * * *$ & $* * *$ \\
L-C & $* * *$ & $* * *$ & $* * *$ \\
S-C & $* * *$ & $* *$ & $*$ \\
L-S & $* * *$ & $* * *$ & NS \\
Line $\times$ Dev temp & $* * *$ & $* * *$ & $* * *$ \\
L-C & $* * *$ & NS & NS \\
S-C & NS & $* * *$ & $* * *$ \\
L-S & $* * *$ & & $* * *$ \\
(b) & & $* * *$ & \\
Dev temp & $* * *$ & $* * *$ & $* * *$ \\
Line & $* * *$ & $* * *$ & $* * *$ \\
L-C & $* * *$ & $* * *$ & $* * *$ \\
S-C & $* * *$ & $* * *$ & NS \\
L-S & $* * *$ & NS & NS \\
Line $\times$ Dev temp & $* *$ & NS & NS \\
L-C & NS & NS & NS \\
S-C & NS & NS & NS \\
L-S & $* *$ & & \\
\hline
\end{tabular}

Wing length selection lines raised at $17.5^{\circ} \mathrm{C}, 20^{\circ} \mathrm{C}, 22.5^{\circ} \mathrm{C}, 25^{\circ} \mathrm{C}$ and $27.5^{\circ} \mathrm{C}$.

(a) Lines selected at $20^{\circ} \mathrm{C}$. (b) Lines selected at $25^{\circ} \mathrm{C}$.

${ }^{*} P<0.05 ;{ }^{* *} P<0.01 ;{ }^{* * *} P<0.001$.

$22.5^{\circ} \mathrm{C}, 25^{\circ} \mathrm{C}$ and $27.5^{\circ} \mathrm{C}$ in generation 18 . Similar exchanges were performed with the $25^{\circ} \mathrm{C}$ wing length selection lines, but then in generations 10 and 25. In exchange III, all thorax length selection lines were reared at $20^{\circ} \mathrm{C}$ and $25^{\circ} \mathrm{C}$ in generation 10 (maximum 150 eggs per vial).

\section{Results}

\section{Parent-offspring analysis and artificial selection}

The response of selection for long wings and short wings at both $20^{\circ} \mathrm{C}$ and $25^{\circ} \mathrm{C}$ (Fig. 1a,b) resulted in realized heritabilities that were smaller than the heritabilities found in the parent-offspring analysis (Table 1). Co-heritabilities (Table 1a), i.e. regression of thorax length in offspring on wing length in parents and vice versa, reflected the high additive genetic correlation $\left(r_{\mathrm{A}}\right)$ between thorax length and wing length, of $r_{\mathrm{A}}=0.698$ at $20^{\circ} \mathrm{C}$ and $r_{\mathrm{A}}=0.839$ at $25^{\circ} \mathrm{C}$.

Surprisingly, thorax length showed hardly any response to directional selection at the two temperatures (Fig. 1c,d), resulting in very low realized heritabilities (Table 1c). In particular, selection for a larger thorax did not lead to any response at all, despite the high heritability in the parent-offspring analysis.

Whereas co-heritabilities between wing length and thorax length were quite substantial in the parentoffspring analyses (Table 1a), realized co-heritabilities were far smaller and sometimes not present at all in the selection lines (Table $1 b, c)$.

\section{Temperature exchange experiments}

Because the two subsets of flies (selected at $20^{\circ} \mathrm{C}$ and at $25^{\circ} \mathrm{C}$ ) are two independent groups, no direct comparison between the two selection temperatures can be made. Therefore, two-way ANOVAs with factors line and developmental temperature were performed per selection temperature (Tables 2 and 3; Figs 2, 3 and 4). At each selection temperature, all trait means differed significantly between selection lines after prolonged selection on wing length (exchange II, Table 2). Developmental temperature had a strong effect on all characters in the three exchange experiments in all lines. In exchange I, developmental temperature did not yet show any interactions with line (data not shown), whereas significant interaction effects were observed in 
Table 3 Two-factor ANOvA with factors line and developmental temperature on characteristics measured in female flies in exchange experiment III

\begin{tabular}{lccc}
\hline & Wing length & Ln (cell number) & Ln (cell size) \\
\hline (a) & & & \\
Dev temp & $* * *$ & $* * *$ & $* * *$ \\
Line & NS & $* * *$ & $* * *$ \\
L-C & $*$ & $* * *$ & $* *$ \\
S-C & NS & NS & NS \\
L-S & NS & $* *$ & $* * *$ \\
Line $\times$ Dev temp & $*$ & $* *$ & $* * *$ \\
L-C & NS & $* *$ & $* *$ \\
S-C & $* *$ & $*$ & NS \\
L-S & S & NS & $* * *$ \\
(b) & & & \\
Dev temp & $* * *$ & $* * *$ & $* * *$ \\
Line & $* * *$ & $* *$ & NS \\
L-C & NS & NS & NS \\
S-C & $* * *$ & $*$ & NS \\
L-S & $* * *$ & $* *$ & NS \\
Line $\times$ Dev temp & NS & NS & NS \\
L-C & NS & NS & NS \\
S-C & NS & NS & $*$ \\
L-S & NS & S & $*$ \\
\hline
\end{tabular}

Thorax length selection lines raised at $20^{\circ} \mathrm{C}$ and $25^{\circ} \mathrm{C}$. (a) Lines selected at $20^{\circ} \mathrm{C}$. (b) Lines selected at $25^{\circ} \mathrm{C}$.

${ }^{*} P<0.05 ;{ }^{* *} P<0.01 ;{ }^{* * *} P<0.001$.

exchange II: selection over 7-10 generations did not yet have an effect on phenotypic plasticity of the traits, as was seen in exchange I (Fig. 2), whereas prolonged selection (exchange II) significantly affected the plasticity of the traits (Fig. 3 and Table 2). In exchange II, a different reaction was observed at each selection temperature: in the $25^{\circ} \mathrm{C}$ wing lines, the changes in mean values of wing length, cell number and cell size were not accompanied by a change in their plasticity (Fig. $3 \mathrm{~d}-\mathrm{f}$ ). In contrast, in the $20^{\circ} \mathrm{C}$ wing lines, the increase in wing length and cell number in the long line was observed, together with an increase in the plasticity of these two characters (Table 2a, Fig. 3a,b). In the $20^{\circ} \mathrm{C}$ short wing line, the decrease in wing length was accompanied by a decrease in cell size but by an increase in the plasticity of cell size (Fig. 3c). The thorax length selection lines in exchange III showed a similar reaction to that of the wing length lines in exchange II: none of the traits in the thorax selection lines at $25^{\circ} \mathrm{C}$ showed significant interactions between line and developmental temperature (Table 3 and Fig. 4d-f). However, the long thorax line selected at $20^{\circ} \mathrm{C}$ showed a significant change in the mean value of cell number and cell size as well as in plasticity (Fig. 4b,c).
At each selection temperature and at each selection regime (wing length selection or thorax length selection), a change in wing length differed in the concomitant reactions of cell number and cell size. Selection on wing length greatly affected cell number and had a smaller effect on cell size. Cell number reacted more strongly to selection at $25^{\circ} \mathrm{C}$ than to selection at $20^{\circ} \mathrm{C}$, as was confirmed by a regression analysis (Table 4a). This effect was highest in exchange experiment II (Table 4b). In the $20^{\circ} \mathrm{C}$ thorax length lines, changes in wing length resulting from different developmental temperatures were caused predominantly by a change in cell number rather than by a change in cell size (Table $4 \mathrm{c}$ ). In contrast, in the $25^{\circ} \mathrm{C}$ thorax length lines, the cell size and cell number contributed about equally to changes in wing length.

\section{Discussion}

Flies with different mean values of wing length and thorax length were obtained to investigate the interrelation between the change in the means of different wing characters and the change in their plasticity. Artificial selection on wing length and thorax length in Drosophila melanogaster has been performed at $20^{\circ} \mathrm{C}$ and $25^{\circ} \mathrm{C}$ separately. As selection 
in each line has been executed at only one temperature, no direct selection on plasticity has been performed.

Heritabilities in the parent-offspring (P-O) regression and realized heritabilities $\left(h^{2}\right)$ showed several differences (Table 1). First, wing length at $20^{\circ} \mathrm{C}$ had a very low $\mathrm{P}-\mathrm{O} h^{2}$, which might be explained by the fact that hardly any offspring emerged and only 20 individuals could be measured. Secondly, an overestimate with a $\mathrm{P}-\mathrm{O}$ regression is not uncommon (Falconer, 1989). Thirdly, realized heritabilities were lower than $h^{2}$ in the $\mathrm{P}-\mathrm{O}$ regression. An explanation could be that the calculations of the realized $h^{2}$ values (Table $1 \mathrm{~b}$ and c) are based on female flies only. Furthermore, when lines are selected identically but at different temperatures, the response to selection can vary. Jinks \& Connolly (1973) found that selection lines respond better in a specific environment when it is more related to the natural environment of the organism. As Drosophila becomes smaller at higher temperatures, lines selected for small body size are expected to respond better to selection at higher temperatures, and vice versa. Only our wing length lines selected at $25^{\circ} \mathrm{C}$ showed such a trend in realized heritability (Table 1b). If we had started more lines and had measured larger samples, different results might have been found.

According to Via \& Lande (1985) and Via (1987), a high additive genetic correlation between two character states indicates a low degree of genetic variation in phenotypic plasticity. As a high additive genetic correlation of wing length between $20^{\circ} \mathrm{C}$ and $22^{\circ} \mathrm{C}\left(r_{\mathrm{A}}=0.949\right)$ existed (E. J. K. Noach, unpublished observations), a change in the plasticity of the wing length characters was, in Via's view, expected to be small. However, after prolonged selection (exchange II), the plasticity of wing length and cell number of the $20^{\circ} \mathrm{C}$ long wing line and the plasticity of cell size in the $20^{\circ} \mathrm{C}$ short wing line have been changed significantly (Fig. 3 and Table 2). The plasticity of none of the $25^{\circ} \mathrm{C}$ selection lines changed,
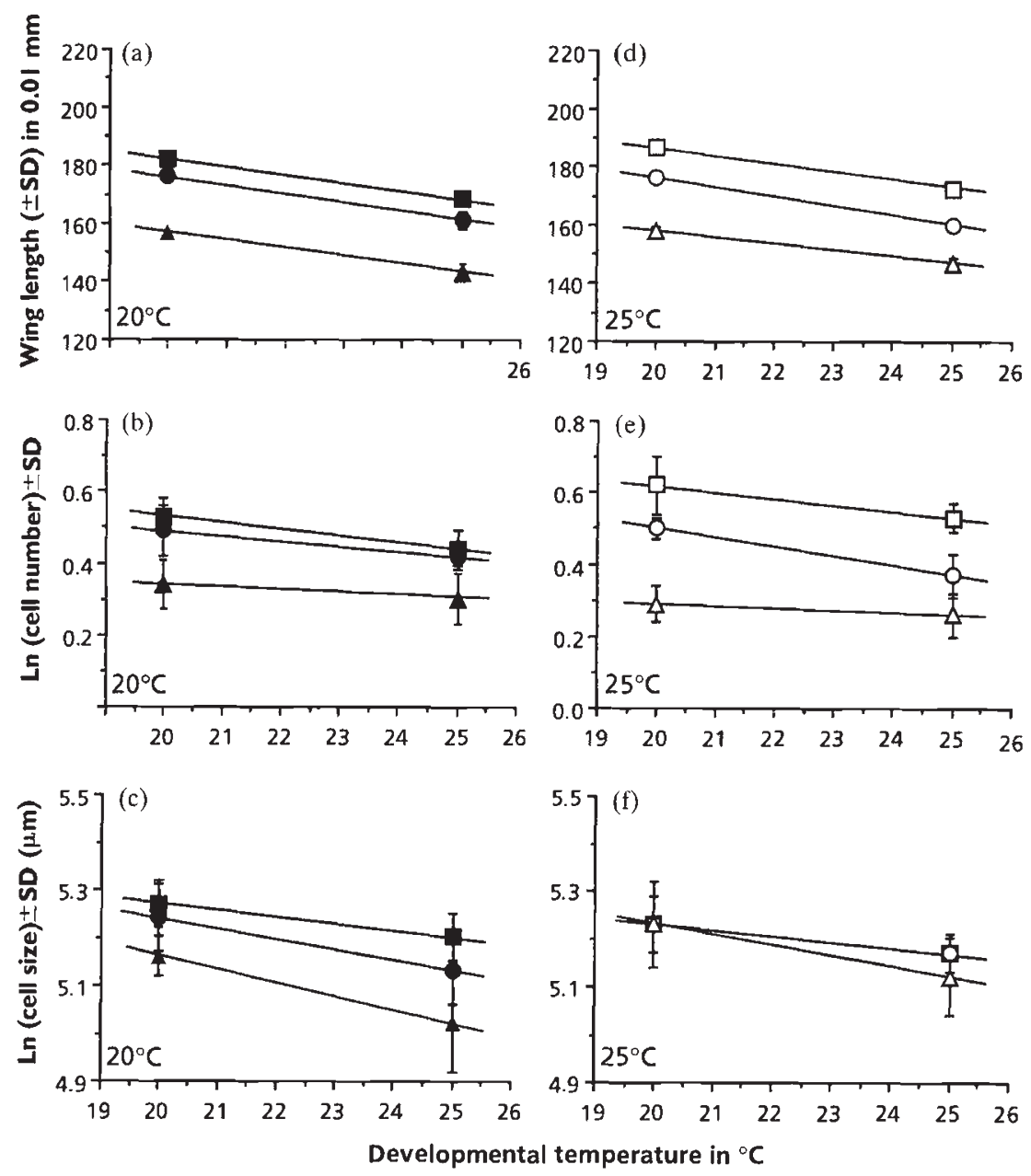

Fig. 2 Exchange experiment I.

Female flies of the lines selected on wing length are raised at $20^{\circ} \mathrm{C}$ and $25^{\circ} \mathrm{C}$. (a) Wing length $( \pm \mathrm{SD})$ of the lines selected at $20^{\circ} \mathrm{C}$. (b) Cell number $( \pm \mathrm{SD})$ of the lines selected at $20^{\circ} \mathrm{C}$. (c) Cell size $( \pm \mathrm{SD})$ of the lines selected at $20^{\circ} \mathrm{C}$. (d) Wing length $( \pm \mathrm{SD})$ of the lines selected at $25^{\circ} \mathrm{C}$. (e) Cell number $( \pm \mathrm{SD})$ of the lines selected at $25^{\circ} \mathrm{C}$. (f) Cell size $( \pm \mathrm{SD})$ of the lines selected at $25^{\circ} \mathrm{C}$. SDs of wing length ( $a$ and $d$ ) are too small to be visible. Lines selected at $20^{\circ} \mathrm{C}$ were exchanged in generation 7 , lines selected at $25^{\circ} \mathrm{C}$ in generation 10. and $\square$, long lines; and $O$, control lines; $\boldsymbol{\Delta}$ and $\triangle$, short lines. 
notwithstanding the considerable change in the mean values of the traits. The conclusion is that at the lower selection temperature both the mean values of the wing characters and their plasticity change, whereas at the higher selection temperature only the mean performance changes.

By selecting in an antagonistic way (i.e. selection in the opposite direction to the environmental reaction), the environmental sensitivity or plasticity of a trait should decrease, whereas the environmental sensitivity or plasticity of a trait should increase with synergistic selection (Jinks \& Connolly, 1973; Falconer, 1990). An antagonistic response was anticipated in the $20^{\circ} \mathrm{C}$ short lines and in the $25^{\circ} \mathrm{C}$ long lines. Hardly any change or reduction in plasticity by antagonistic selection has been found in our data. A synergistic response was expected in our $20^{\circ} \mathrm{C}$ long lines and in the $25^{\circ} \mathrm{C}$ short lines, but was only observed in the wing length of the $20^{\circ} \mathrm{C}$ long wing line in exchange II, and not in the $25^{\circ} \mathrm{C}$ short wing line. A correlated increase in the plasticity of cell number was observed in this same $20^{\circ} \mathrm{C}$ long wing line.

Differences in wing length are caused by differences in cell size, in cell number or in both. A genetic increase in cell size has often been found to be associated with low temperature of maintaining stocks, whereas a developmental increase in cell size is often observed at lower developmental temperatures (Robertson, 1959a; Cavicchi et al., 1985; Partridge et al., 1994). Our results conform to these trends: comparing the mean performance (i.e. the performance at $22.5^{\circ} \mathrm{C}$ ) of the wing length of the two control lines in exchange II, a slightly larger wing with fewer, but somewhat larger, cells is observed in the $20^{\circ} \mathrm{C}$ line. A change in cell number has been found in artificial selection for body size (Robertson, 1959b). The wing length selection lines in exchange II indeed show a main effect on cell number, and a much lower effect on cell size. However, cell number and cell size can also behave as independent characters when selection on wing length is performed: the
Fig. 3 Exchange experiment II. Female flies of the lines selected on wing length are raised at $17.5^{\circ} \mathrm{C}$, $20^{\circ} \mathrm{C}, 22.5^{\circ} \mathrm{C}, 25^{\circ} \mathrm{C}$ and $27.5^{\circ} \mathrm{C}$. (a) Wing length $( \pm \mathrm{SD})$ of the lines selected at $20^{\circ} \mathrm{C}$. (b) Cell number $( \pm \mathrm{SD})$ of the lines selected at $20^{\circ} \mathrm{C}$. (c) Cell size $( \pm S D)$ of the lines selected at $20^{\circ} \mathrm{C}$. (d) Wing length $( \pm \mathrm{SD})$ of the lines selected at $25^{\circ} \mathrm{C}$. (e) Cell number $( \pm \mathrm{SD})$ of the lines selected at $25^{\circ} \mathrm{C}$. (f) Cell size $( \pm \mathrm{SD})$ of the lines selected at $25^{\circ} \mathrm{C}$. Lines selected at $20^{\circ} \mathrm{C}$ were exchanged in generation 18; lines selected at $25^{\circ} \mathrm{C}$ in generation $25 . \square$ and $\square$, long lines; - and $O$, control lines; $\Delta$ and $\Delta$, short lines.
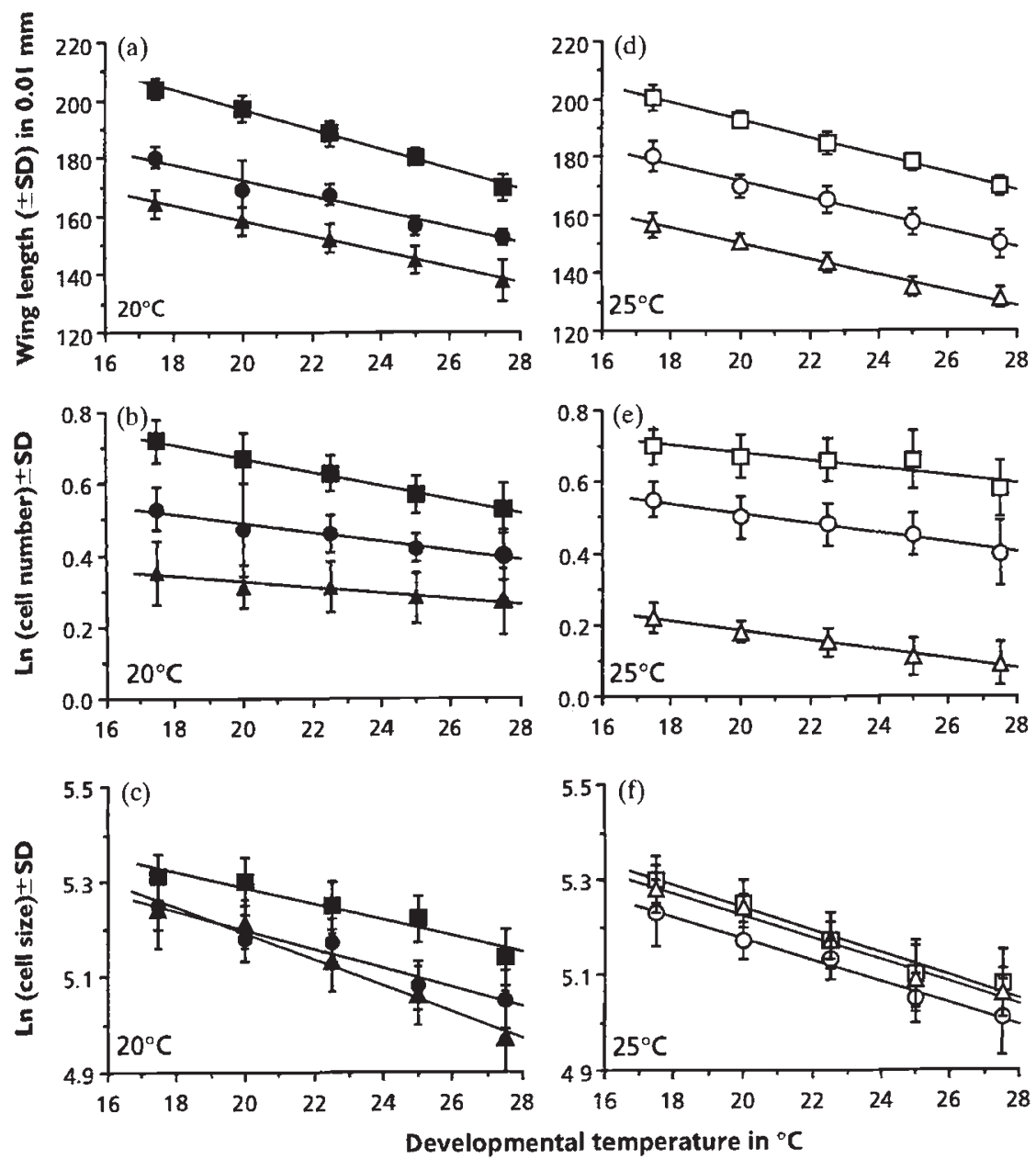
$20^{\circ} \mathrm{C}$ long line obtained a long wing with extra large cells, whereas the $25^{\circ} \mathrm{C}$ short line developed a small wing with extremely few, but relatively large, cells (Table 4). Furthermore, a plastic response in cell number is observed in the $20^{\circ} \mathrm{C}$ long line, a reaction that has rarely been reported in the literature. The conclusion is that changes in wing length are not strictly divided into a change in cell size, when environmental conditions differ, and a change in cell number as a consequence of artificial selection.

Scheiner \& Lyman $(1989,1991)$ concluded from their experiments that separate genes exist for trait values and their plasticity. However, if the plasticity of a trait and the trait mean are genetically correlated, a correlated effect of directional selection in trait and trait plasticity should be observed (Via,
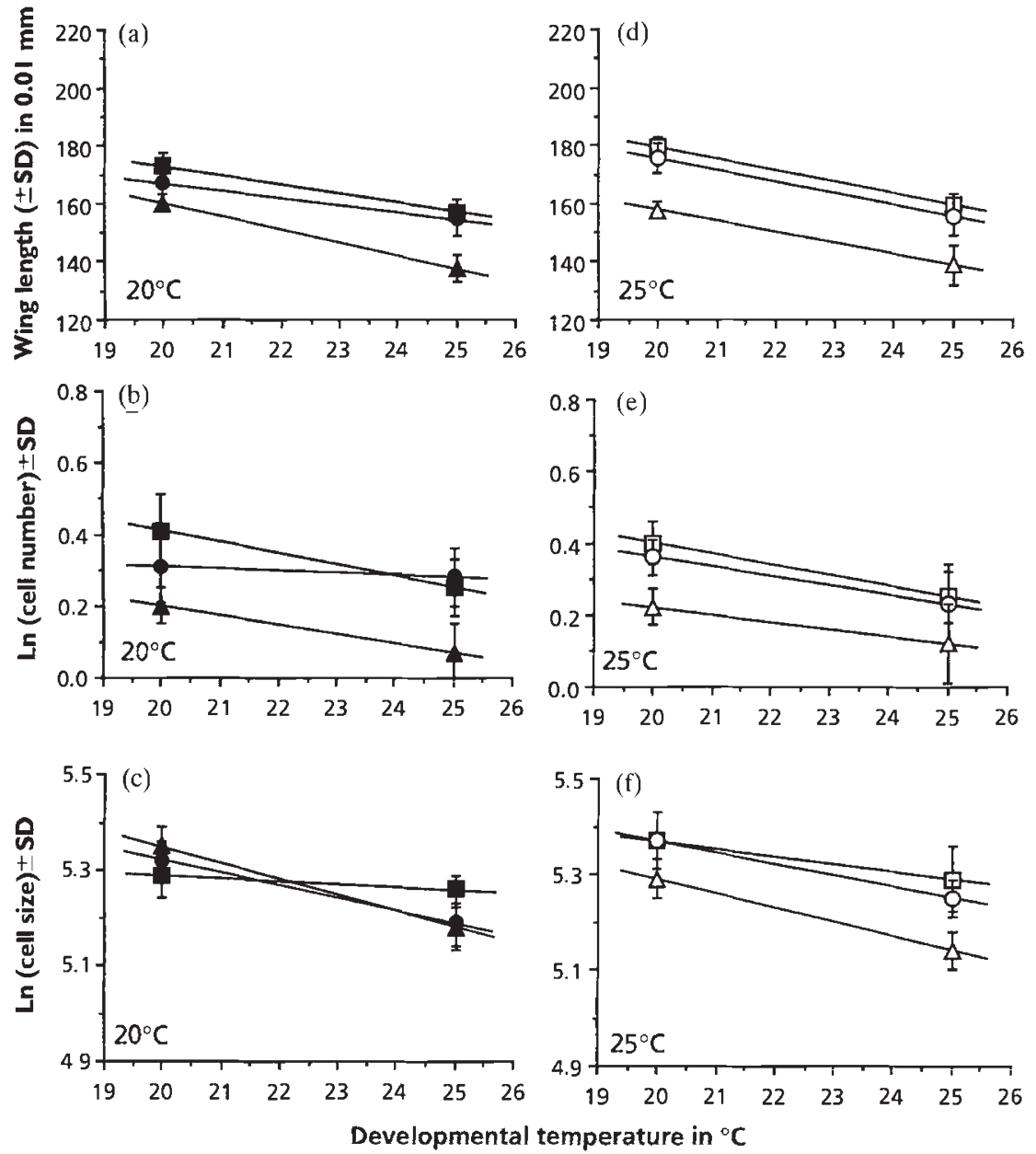

Fig. 4 Exchange experiment III. Female flies of the lines selected on thorax length are raised at $20^{\circ} \mathrm{C}$ and $25^{\circ} \mathrm{C}$. (a) Wing length $( \pm \mathrm{SD})$ of the lines selected at $20^{\circ} \mathrm{C}$. (b) Cell number $( \pm \mathrm{SD})$ of the lines selected at $20^{\circ} \mathrm{C}$. (c) Cell size $( \pm \mathrm{SD})$ of the lines selected at $20^{\circ} \mathrm{C}$. (d) Wing length $( \pm \mathrm{SD})$ of the lines selected at $25^{\circ} \mathrm{C}$. (e) Cell number $( \pm \mathrm{SD})$ of the lines selected at $25^{\circ} \mathrm{C}$. (f) Cell size $( \pm \mathrm{SD})$ of the lines selected at $25^{\circ} \mathrm{C}$. All lines were exchanged after 10 generations of selection. $\square$ and $\square$, long lines; $\bullet$ and $\mathrm{O}$, control lines; $\triangleleft$ and $\triangle$, short lines.

Table 4 Model II regressions (Sokal \& Rohlf, 1981; box 14.12) on contribution of cell size and cell number to changes in wing area in female flies in the temperature exchange experiments

\begin{tabular}{|c|c|c|c|c|c|c|}
\hline \multirow{2}{*}{$\begin{array}{l}\text { Selection } \\
\text { temperature }\end{array}$} & \multicolumn{2}{|c|}{ (a) } & \multicolumn{2}{|c|}{ (b) } & \multicolumn{2}{|c|}{ (c) } \\
\hline & Cell number $(\%)$ & Cell size $(\%)$ & Cell number $(\%)$ & Cell size $(\%)$ & Cell number $(\%)$ & Cell size $(\%)$ \\
\hline $20^{\circ} \mathrm{C}$ & 56 & 44 & 72 & 28 & 77 & 23 \\
\hline $25^{\circ} \mathrm{C}$ & 92 & 8 & 99 & 1 & 57 & 43 \\
\hline
\end{tabular}

(a) Exchange I, wing length selection lines. (b) Exchange II, wing length selection lines. (c) Exchange III, thorax length selection lines. In exchanges I and III, lines were reared at $20^{\circ} \mathrm{C}$ and $25^{\circ} \mathrm{C}$; in exchange II, the wing length lines were reared at $17.5^{\circ} \mathrm{C}, 20^{\circ} \mathrm{C}, 22.5^{\circ} \mathrm{C}, 25^{\circ} \mathrm{C}$ and $27.5^{\circ} \mathrm{C}$. 
1987; de Jong, 1995). Both situations occur in our wing length lines. A change in trait mean in the $20^{\circ} \mathrm{C}$ lines is often accompanied by a change in plasticity. In the $25^{\circ} \mathrm{C}$ lines, no change in plasticity is observed in spite of large changes in trait means. This difference in correlated response between the two selection temperatures could occur when some genes are activated at one temperature but not at another. Such a situation would correspond with Gromko's (1995) model for correlated response.

Our result might have been different if more selection lines had been started from the same population. However, it was not possible to measure larger samples; the small samples might have caused random drift in the selection lines. The results of our $20^{\circ} \mathrm{C}$ selection lines do not contradict Via's model, in which the value of a trait in different environments is the primary focus; no independent change in trait mean and plasticity occurred. However, an independent change in trait mean and in plasticity is observed in our $25^{\circ} \mathrm{C}$ selection lines. If wing size and its plasticity are determined by different combinations of genes, the results of all our selection lines can fit Scheiner \& Lyman's (1989, 1991) ideas.

\section{Acknowledgements}

The authors would like to thank Diana van Dam, Linda van Oosterhout, Jolanda van Deurzen, Lenny Kouwenberg and Mario van der Hoeven for starting the selection lines and performing the exchange experiments, Dr Maarten Terlou for developing the IBAS program to measure wing cells, Cas Kruitwagen for help with the statistical analysis of the data, Dick Smit for drawing the figures and Tonio Andrade for help with the English language.

\section{References}

BRADSHAw, A. D. 1965. Evolutionary significance of phenotypic plasticity in plants. Adv. Genet, 13, 115-155.

CAVICCHI, S., GUERRA, D., GIORGIO, G. AND PEZZOLI, C. 1985. Temperature-related divergence in experimental populations of Drosophila melanogaster. I. Genetic and developmental basis of wing size and shape variation. Genetics, 109, 665-689.

DE JONG, G. 1995. Phenotypic plasticity as a product of selection in a variable environment. Am. Nat., 145, 493-512.

DOBZHANSKY, TH. 1929. The influence of the quantity and quality of the chromosomal material on the size of the cells in Drosophila melanogaster. Arch. Entwicklungsmech. Organ, 115, 363-379.

FALCONER, D. S. 1952. The problem of environment and selection. Am. Nat., 86, 293-298.
FAlCONER, D. S. 1989. Introduction to Quantitative Genetics, 3rd edn. Longman, New York.

FALCONER, D. S. 1990. Selection in different environments: effects on environmental sensitivity (reaction norm) and on mean performance. Genet. Res., 56, 57-70.

GROMко, м. H. 1995. Unpredictability of correlated response to selection: pleiotropy and sampling interact. Evolution, 49, 685-693.

JINKS, J. L. AND CONNOLLY, v. 1973. Selection for specific and general response to environmental differences. Heredity, 30, 33-40.

MITTLER, S. AND BENNETT, J. 1962. A simple food medium that requires no live yeast with a minimum of variables. Drosoph. Inf. Serv., 36, 131-132.

PARTRIDGE, L., BARRY, B., FOWLER, K. AND FRENCH, V. 1994. Evolution and development of body size and cell size in Drosophila melanogaster in response to temperature. Evolution, 48, 1269-1276.

REEVE, E. C. R. 1961. A note on non-random mating in progeny tests. Genet. Res., 2, 195-203.

ROBERTSON, F. w. 1959a. Studies in quantitative inheritance XII. Cell size and number in relation to genetic and environmental variation of body size in Drosophila. Genetics, 44, 869-896.

ROBERTSON, F. W. 1959b. Studies in quantitative inheritance XIII. Interrelations between genetic behavior and development in the cellular constitution of the Drosophila wing. Genetics, 44, 1113-1130.

Robertson, F. W. AND REEVE, E. C. R. 1952. Studies in quantitative inheritance. I. The effects of selection of wing and thorax length in Drosophila melanogaster. $J$. Genet., 50, 414-448.

SCHEINER, S. M. 1993. Plasticity as a selectable trait: reply to Via. Am. Nat., 142, 371-373.

SCHEINER, S. M. AND LYMAN, R. F. 1989. The genetics of phenotypic plasticity. I. Heritability. J. Evol. Biol., 2, 95-107.

SCHEINER, S. M. AND LYMAN, R. F. 1991. The genetics of phenotypic plasticity. II. Response to selection. J. Evol. Biol., 4, 23-50.

SCHLichting, C. D. 1993. Control of phenotypic plasticity via regulatory genes. Am. Nat., 142, 366-370.

SOKAL, R. R. AND ROHLF, F. J. 1981. Biometry, 2nd edn. W.H. Freeman, San Francisco.

VIA, s. 1987. Genetic constraints on the evolution of phenotypic plasticity. In: Loeschcke, V. (ed.) Genetic Constraints on Adaptive Evolution, pp. 47-71. SpringerVerlag, Berlin.

viA, s. 1993. Adaptive phenotypic plasticity: target or by-product of selection in a variable environment? $\mathrm{Am}$. Nat., 142, 352-365.

VIA, S. AND LANDE, R. 1985. Genotype-environment interaction and the evolution of phenotypic plasticity. Evolution, 39, 505-522.

VIA, s., GOMULKIEWICZ, R., DE JONG, G., SCHEINER, S. M., SCHLiCHTING, C. D. AND VAN TIENDEREN, P. 1995. Adaptive phenotypic plasticity: consensus and controversy. Trends Ecol. Evol., 10, 212-217. 